\title{
IMPLEMENTATION OF FOREIGN EXPERIENCE IN GOVERNMENT PROCUREMENT INTO THE NATIONAL ECONOMY OF THE REPUBLIC OF UZBEKISTAN
}

\author{
Akramov Azamat, Tashkent Institute of Finance, Independent researcher, Uzbekistan \\ Rano Isakovna Mardanova, Dr., Tashkent Institute of Finance, Uzbekistan \\ DOI: https://doi.org/10.31435/rsglobal_conf/25012021/7362
}

\begin{abstract}
The experience of Western countries with a developed market infrastructure shows that the public procurement system naturally became an integral part of the sphere of internal commodity exchange of certain types of products and services and one of the mechanisms for maintaining competition and a liberal way of doing business. The objective basis for the existence and progressive development of the public procurement system in the national economy of many countries is the fact that in the process of fulfilling their target functions, individual government departments and organizational structures of any of them are forced to face the problem of material and technical support both for the implementation of state and local programs, and for the implementation of their current activities. As a rule, it is solved by purchasing the necessary material and intangible resources, goods, works and services through purchases, called state, in the process of specially organized competitive bidding. The purpose of this article is to show the experience of developed countries in the implementation of public procurement.
\end{abstract}

Keywords: government procurement, efficiency, demand, supply, investment, fixed capital, income, profit, economic growth, market, market demand, economic fluctuations, inflation, money supply, price level, innovation, competition, budget, tax policy.

Introduction. Many developing countries in the recovery of the national economy are faced with many problems in resolving issues of efficiency. There is always a question about the correct allocation of limited resources. Due to the fact that resources are always in the economy in limited quantities, the issue of their use is always in the focus of the country's economic policy. The transition of the economy always means the transformation of the economic system. Therefore, it is required and also necessary to refer to foreign economic experience. The state plays a special role in transforming the economy. Acting as a customer, in turn, the state plays an important role and influence on the development of the economy. The market economy is based on free market mechanisms, where both demand and supply play the main role. In turn, the state also acts as a buyer, that is, the main customer. Therefore, there is such a question in a market economy, how to make sure that by buying goods and services, the state can effectively influence the economy as a whole. What mechanism should be introduced in the structure of public procurement in order for all economic entities to benefit from this, as well as the entire economy as a whole.

The study of a significant period of foreign practice in the use of the public procurement system indicates that its emergence and further development is closely related to the strengthening of the role of the state, the transformation and improvement of the forms of government. Despite the fact that in developed countries by now the goals of public procurement and the mechanisms of their organization have undergone significant changes, two of their characteristic features have remained unchanged. First of all, this is the nature of interaction between the state and representatives of the business community in the system of contractual relations regarding the procurement of goods, works or services, as well as the principle of their payment - at the expense of the state budget. A prerequisite for a significant increase in the physical and cost volumes of public procurement in the second half of the last century in most countries, especially European ones, was the problem of the need to restore and build large national infrastructure facilities. This, in turn, required significant public financial investments and intensive involvement in this process of various economic entities from among the manufacturers and suppliers of products, works and services. In addition, the experience of working with business structures in the field of state defense orders, accumulated by the governments of individual countries (USA, Germany, Great Britain, Japan), as well as achievements in the field of communication technologies, made it possible to transfer its positive aspects to the system of relations 
in the area of public procurement in the field of civil engineering [6]. There are several ways to conduct government procurement. One of them is the competitive mechanism.

The competitive mechanism, especially in case of bulk purchases, allows achieving several solutions - reducing the cost of the products required by the customer, ensuring a higher level of transparency and accountability of the purchase and sale process, and ultimately resisting corruption.

\section{Materials and methods.}

The study of a significant period of foreign practice in the use of the public procurement system indicates that its emergence and further development is closely related to the strengthening of the role of the state, the transformation and improvement of the forms of government. Despite the fact that in developed countries by now the goals of public procurement and the mechanisms of their organization have undergone significant changes, two of their characteristic features have remained unchanged. First of all, this is the nature of the interaction of the state with representatives of the business community in the system of contractual relations regarding the procurement of goods, works or services, as well as the principle of their payment - at the expense of the state budget. A prerequisite for a significant increase in the physical and cost volumes of public procurement in the second half of the last century in most countries, especially European ones, was the problem of the need to restore and build large national infrastructure facilities. This, in turn, required significant public financial investments and intensive involvement in this process of various economic entities from among the manufacturers and suppliers of products, works and services. In addition, the experience of working with business structures in the field of state defense orders, accumulated by the governments of individual countries (USA, Germany, Great Britain, Japan), as well as achievements in the field of communication technologies, made it possible to transfer its positive aspects to the system of relations in the area of public procurement in the field of civil engineering. Thus, this period was the beginning of an active stage in the development of public procurement processes in Western countries. At the same time, in most of them, the basic principles of the functioning of a market economy emerged, a market for the means of production appeared and competitive conditions were created, the business sector, including small and medium-sized businesses developed and expanded rapidly. An important stage in the development of the system of public procurement abroad was a ten-year period, which was characterized by the exit of processes in this area of activity outside the national markets. At the same time, the first special interstate directives on the regulation of public procurement within the European Union countries were adopted $(1971,1976)$ [6]. Somewhat later, in 1981, the GATT Agreement "On Public Procurement" came into force, which was aimed at facilitating the access procedures for foreign companies supplying products to national markets to participate in tenders. The current stage of development of the public procurement system in international practice, starting from the 90s of the XX century, is characterized by new features [9]. This is largely due to the manifestations of the globalization of the world economy and the liberalization of economic activity, which could not but affect the change in the role and functions of the state, including in the field of government orders in industrialized countries. A noticeable phenomenon has become the fact that the state is now an active subject of market relations, actively participating in production, trade, investment, innovation and socio-economic processes through the system of public procurement. In addition, government purchases abroad themselves have become one of the main instruments for the implementation of long-term and large-scale on-farm programs - in the construction of power plants, transport networks, oil and gas pipelines; creation of large industrial facilities, land reclamation work, as well as in the framework of social and educational projects.

From this period onwards, the term "government procurement system" was used in relation to public procurement in Western countries. At the same time, the principles of economy and efficiency in the processes of spending funds for these purposes have acquired particular importance. The prerequisites for this were the realization by the national governments of a number of developed states of the complex and interrelated nature of the public procurement processes, including in the system of relations between their participants. In the process of evolutionary development, the public procurement system in the practice of developed countries has turned from a means of meeting the current needs of state and local structures and solving problems of ensuring national defense into one of the most important tools for regulating the economy. The experience gained indicates that their advantage is expressed in the expansion of the independence and initiative of supplier enterprises in market conditions of management. First of all, this was due to the fact that in such a situation the state in the public procurement system acts as an equal economic entity and a participant in the competitive process.

Modern foreign practice in the field of government procurement shows that the necessary acquisitions by the state through the state order are carried out mainly to solve problems of meeting current 
state needs for certain types of goods, works and services. In addition, in order to replenish the state food reserve through government orders and implement individual investment projects, funds from international financial organizations (IBRD, EBRD), as well as foreign regional development banks are used [9].

In general, public procurement costs in most developed countries are covered from the state or territorial budgets, special government and extra-budgetary funds, formed from tax and other types of revenues, including revenues from the activities of government agencies themselves. Sources of financing for government procurement abroad are shown using the example of Uzbekistan in Figure 1.

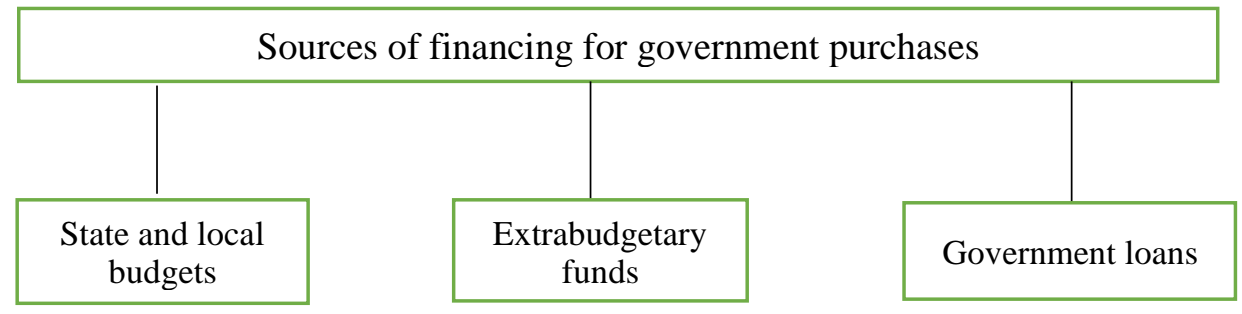

Fig. 1. Source: made by author

Discussion. Meanwhile, one of the problems in terms of a real assessment of the volume of national public procurement is the absence of a separate item for accounting for their financing in the composition of the expenditure side of the state budget of most countries. In international practice, it is customary to estimate the total volume of public procurement based on the cost of services produced in the public sector, that is, on the basis of costs incurred in connection with the performance by government agencies of their target functions, including the acquisition of inventory items necessary for this. Their aggregate size is usually calculated on the basis of data on government intermediate or final consumption.

The problem is aggravated by the lack of a unified methodology for determining the value of government procurement, a standard classification of the product range, and, most importantly, an information base on reliable indicators of the state of the public procurement sector in the context of individual countries. So, at the moment there are three sources of statistical information on the cost of national government orders. These are data from international economic organizations (IMF, OECD, WTO, World and European Development Banks), specially authorized state bodies, as well as commercial companies supplying goods, works and services through public procurement [12]. With varying degrees of detail and representativeness, they reflect the volume and structure of national public procurement. However, estimates show that their information base often turns out to be incomparable both in terms of the nomenclature and the total volume of purchases, which is due to a number of reasons. Firstly, due to the fact that the understanding of public procurement in foreign practice is ambiguous, for example, in the EU countries they are associated with the purchase of products and services for public purposes (public procurement), and in other countries this includes procurement for state needs (government procurement) [14]. Moreover, the first of them is much broader, since it includes meeting the needs of not only state enterprises and institutions, but also utilities, and most realistically reflects the financial costs of the state for these purposes. That is why the value of the public procurement market in European countries, according to the Commission of the European Community (EEC), is usually higher than the OECD estimates, since they include only budgetary expenditures on the procurement of goods and services for public needs [12].

Secondly, the discrepancy in international statistics on the cost of public procurement in the context of countries is caused by the confidentiality of some information on government spending on the purchase of relevant products for the needs of the national army, its defense capability and security. Largely for this and other reasons, the IMF, for example, in its statistics takes into account the cost of military uniforms as part of budget allocations for the purchase of goods for public needs, and the OECD includes them in the item "payments to civil servants"[2].

Results. As a result, according to foreign experts, by the end of the 90s of the twentieth century, the indicators of the share of government orders in 20 WTO member countries were underestimated by more than $11 \%$ [6].

So, according to their own estimates, taking into account the values of 140 countries, the global public procurement market by the beginning of 2010 was estimated at 5.5 trillion dollars, which was equivalent to $82.3 \%$ of world exports of goods and services (Table 1). Of these, 4.8 trillion dollars $(85.7 \%)$ accounted for countries in the OECD [6]. 
Over the past 25 years, national purchases in the 15 most developed countries have increased by $\$ 4.4$ trillion, i.e. more than 4 times. Moreover, the US accounts for $46.5 \%$ [4].

Orders for the purchase of goods, services, works for state needs at the present stage are more consistent with the market principles of economic regulation and plays an important role in the economic development of many developed countries. Although the state of the public procurement system itself significantly depends on the level of development of the national economy, the form of government and the specifics of budgetary policy, which has a significant impact on their physical and cost volumes. This interaction can be confirmed by the situation in the mid-90s. the previous century, prevailing in the EU. Carrying out a pan-European one on their territory led to a significant decrease in the volume of state purchases. As a result of the accompanying partial privatization and contracting of a number of non-core activities for state structures, the total financial costs for the production of public services and, accordingly, the size of state purchases decreased. Their share in GDP decreased on average by $0.8 \%$, or 35.3 billion euro [5]. At the same time, privatization processes in most developed countries stimulated the emergence of a significant share of consulting services in public procurement - engineering, audit, management, etc.

Western practice demonstrates that the form of government also affects the degree of centralization of the national public procurement system and the level of its perfection, which in turn affects the ratio of the value of products purchased by enterprises and organizations of various levels of government, and their commodity structure [10]. Thus, a number of OECD countries with a centralized form of government are characterized by higher spending on public procurement at the government level compared to regional and municipal structures.

In modern conditions, the national policy of foreign countries in the field of public procurement is largely influenced by international norms and rules, as well as by the activities of transnational corporations (TNCs), which seek to penetrate the markets of different countries, including through the system of government orders. In addition, the intensifying processes of integration into the world economic system have a significant impact on the development of public procurement within countries, pushing them to accelerate the liberalization of domestic markets [12].

At the present stage, in countries with developed market economies, the social function of the public procurement system has noticeably increased, which is expressed in life support and the provision of guaranteed services to various segments of the population, especially those who represent the so-called risk group [8].

In countries with the most developed market infrastructure, complementary functions of competitive procurement are clearly visible, which are focused on maintaining a stable economic situation in the domestic market, stimulating economic activity in certain industries and spheres, as well as administrative-territorial entities, for the development of innovations and R\&D [4]. All this, as Western practice shows, ultimately contributes to the optimization of state budget expenditures and an increase in the level of national income.

A prerequisite for the manifestation of additional functions in the public procurement system is the significant interest of national and foreign business structures in obtaining a government order, especially as a general contractor. Taking into account that the state, represented by its structures, is the largest national buyer of the relevant types of products, obtaining a state contract by a supplier means, in fact, for any of them the possibility of ensuring production at the expense of the state budget and guaranteed sales of products. And further - the establishment in the domestic market of the predicted level of prices for purchased products, the systematic increase in the efficiency of work on the implementation of government contracts, and their size.

The competitive form of procurement, as you know, allows you to maximize budget savings. According to experts, in developed countries it reaches an average of $14-16 \%$ of the initial price of production and up to $30 \%$ in developing countries [7]. In some situations, these values may be even higher. Thus, according to the OECD, in Italy, the achievement of the European standard for the state to hold open tenders for the purchase of cars for high-speed trains led to a 30\% decrease in their cost [11]. The Brazilian government saves up to $20 \%$ of the budget after the introduction of the Dutch-type auction procedure in electronic form on the Internet [6]. In Colombia, through the use of open government tenders, it was possible to reduce government spending on the purchase of military goods by $47 \%$ [6].

Conclusions. The study of international experience in the field of government procurement convinces that they are capable of becoming a source of growth for the national economy. For developing countries, this situation is an alternative to borrowing and financial assistance from foreign 
financial funds. In particular, OECD studies show that in 37 out of 39 developing countries, a decrease in the level of prices in the process of public procurement by only $10 \%$ leads to budget savings in an amount comparable to the volume of external financial assistance in the form of loans and credits through international credit organizations [6].

The stimulating function of public procurement in the economies of developed countries entails the solution of several problems. First, the state gets the opportunity to demand from national companies in the process of fulfilling a future order, pre-established technical parameters of purchased products, to use innovative technological and other achievements. At the same time, the desire of the producers of goods and services themselves to introduce the most modern production and management technologies allows them to achieve a higher level of product competitiveness. Foreign practice shows that orders placed in such industries, in particular in aircraft and instrument making, are capable of stimulating the development of innovations [10].

Secondly, public procurement makes it possible to select the most competitive representatives from among the manufacturers and suppliers of specific goods and services, as well as executors of work within the framework of the tender. [11] In the long term, these processes lead to savings in public budget resources and the efficiency of their use. At the national level, it also contributes to the strengthening of export potential, industrial restructuring and the development of the marketing system. The ability to combine orders and deliveries of scientific and technical products for the needs of individual government customers leads to the productive use of resources. In general, this leads to an increase in national income.

The stimulating innovative role of public procurement is also manifested in the fact that the state, acting as a customer, is also the "first buyer" of new types of products and samples of experimental products that have not yet become serial. In this case, the government unwittingly shares the risks and benefits of technological projects together with manufacturers, often participating in promising developments from their initial stage to production testing of prototypes of products. Western practice of the last period shows that the cost of innovative developments acquired by the state, especially in such areas as health care, education, energy and the environment, transport services, is about 435 million euros annually in the EU countries and 49 billion dollars in the United States [2]. These figures are equivalent to $5-15 \%$ of the total public procurement in these countries [6].

Thanks to the stimulating function of public procurement, the state strengthens the processes of developing competition in the domestic market, promoting the activity of small and medium-sized businesses by providing them with certain benefits. At the same time, these consequences go beyond the framework of a separate state contract, since, in turn, they stimulate them to conduct tenders in the future for the selection of subcontractors and sub suppliers for the execution of the state order.

\section{REFERENCES}

1. Bykova, N.N., Shaydullova, A.I. Content and principles of formation of incomes of budgets of different levels // Young scientist. - 2019. - No. 14. - S. 141-146.

2. Volkova, A.A. Problems of budgeting at the municipal level / A.A. Volkova // Scientific Almanac. 2017. No. 5-1 (31). S. 64-66.

3. Galukhin A.V. Stability of the budgetary system of the region: problems and ways of their solution / A.V. Galukhin // News of higher educational institutions. Series "Economics, finance and production management". - 2019. - No 2. - C. 41-49.

4. Davydova, N.Yu. The right of the municipality to the local budget: content and forms of implementation / Bulletin of VEGU. 2019. No. 2 (76). S. 20-26.

5. Ermoshina, T.V., Svyatkina, E.A. Development of the mechanism for generating local budget revenues // Young Scientist. - 2020. - No. 9. - S. 601-603.

6. Efimov, Ya.G. The role of the local budget in the socio-economic development of the territory / Ya.G. Efimov // Modern trends in the development of science and technology. 2017. No. 1-7. S. 118-121.

7. Zyryanova, M.A. Assessment of the financial stability of the regional budget using an integral indicator / Bulletin of Science and Education. 2019. No. 5 (7). S. 59-63

8. Karavaeva, Yu.S. Financial independence of regional and local budgets / Yu.S. Karavaeva // Problems and prospects of economics and management: materials of the International conference. scientific. conf. (St. Petersburg, April 2012). - SPb.: Renome, 2018. - S. 73-76.

9. Kozhemyachenko, A.V. Solving the problems of the independence of the budgets of municipalities / A.V. Kozhemyachenko // Scientific notes of PNU. 2019.Vol. 7. No. 4. P. 572-575.

10. Kyshtymova, E.A., Mertsalova, A.A. Analysis and planning of financial results / Collection of articles of the International Scientific and Practical Conference in 3 parts. Resp. ed.: Sukiasyan Asatur Albertovich. 2017. -FROM. 169-172. 
11. Levdonsky, A.A. Fiscal risks and stability of the Federal budget / Economy, entrepreneurship and law. 2018.Vol. 6. No. 2. P. 175-184.

12. Lytneva, N.A., Datiy, I.S. Methods for analyzing directions for optimizing municipal budget expenditures / Fundamental research. 2017. No. 7.P. 162-166.

13. Milyukin, A.N. Concept and structure of the municipal budget / Science Alley. 2017. T. 3. No. -9. S. 185-188.

14. Molvinskikh, N.A. Features of the budget of the municipal formation / N.A. Molvinskikh // Science and Modernity. 2019. No. 37-2. S. 119-122. Mogilev, S. V. Theoretical aspects of the formation of incomes of local budgets // Young scientist. - 2019. - No. 7. Vol. 1. - S. 99-101.

15. Nikitskaya, EF, Gorbacheva, IA Interbudgetary relations in the system of formation of investment sources of financing for innovation activity // Science Science Internet magazine. - 2018 - No. 4 (13). - S. 112.

16. Petrushina, O.V., Sviridova, M.S. To the question of the role of local budgets in the socio-economic development of municipalities // Young scientist. - 2017. - No. 32. - S. 55-58.

17. Rakitina, I.S., Berezina, N. N. State and municipal finance: textbook and workshop for an academic bachelor's degree - Moscow. Yurayt, 2019. - 333. 